\title{
HMT, Rat Strain
}

National Cancer Institute

\section{Source}

National Cancer Institute. HMT, Rat Strain. NCI Thesaurus. Code C14384.

About 50\% incidence of squamous-cell carcinoma of the mouth late in life. Mean lifespan 27-30 months with or without mouth tumors (Hulse 1979, Buckley et al 1980). 